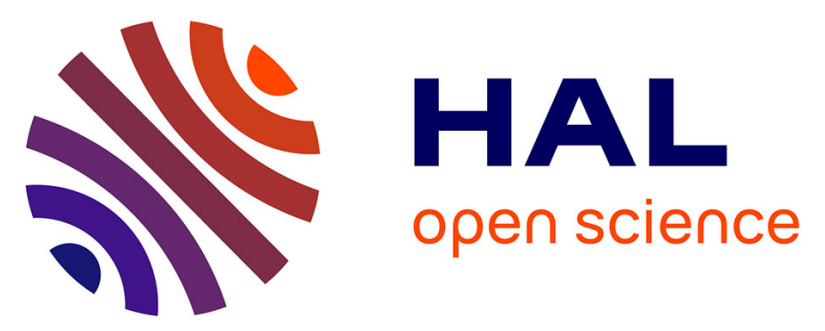

\title{
Vertical change in dissolved organic carbon and oxygen at the water table region of an aquifer recharged with stormwater: biological uptake or mixing?
}

Arnaud Foulquier, Florian Malard, Florian Mermillod-Blondin, T. Datry, Laurent Simon, Bernard Montuelle, Janine Gibert

\section{To cite this version:}

Arnaud Foulquier, Florian Malard, Florian Mermillod-Blondin, T. Datry, Laurent Simon, et al.. Vertical change in dissolved organic carbon and oxygen at the water table region of an aquifer recharged with stormwater: biological uptake or mixing?. Biogeochemistry, 2010, 99 (1-3), pp.31-47. 10.1007/s10533009-9388-7 . halsde-00520892

\section{HAL Id: halsde-00520892 \\ https://hal.science/halsde-00520892}

Submitted on 15 May 2020

HAL is a multi-disciplinary open access archive for the deposit and dissemination of scientific research documents, whether they are published or not. The documents may come from teaching and research institutions in France or abroad, or from public or private research centers.
L'archive ouverte pluridisciplinaire HAL, est destinée au dépôt et à la diffusion de documents scientifiques de niveau recherche, publiés ou non, émanant des établissements d'enseignement et de recherche français ou étrangers, des laboratoires publics ou privés. 
1 Vertical change in dissolved organic carbon and oxygen at the water table

\section{region of an aquifer recharged with stormwater:}

$$
\text { biological uptake or mixing? }
$$

\footnotetext{
${ }^{1}$ Université de Lyon, Lyon, F-69622, France ; Université Lyon 1, Lyon, F-69622, France ; CNRS, UMR 5023, Ecologie des Hydrosystèmes Fluviaux, Villeurbanne, F69622, France.

${ }^{2}$ CEMAGREF, Laboratoire Dynamiques, Indicateurs et Modèles en Ecohydrologie, 3 bis Quai Chauveau, CP 220, 69336 Lyon Cedex 09, France

${ }^{3}$ CEMAGREF, Laboratoire d'Ecologie Microbienne des Hydrosystèmes Anthropisés, 3 bis Quai Chauveau, CP 220, 69336 Lyon Cedex 09, France
}

* Corresponding author

\section{ARNAUD FOULQUIER}

UMR CNRS 5023, Ecologie des Hydrosystèmes Fluviaux,

Université Claude Bernard Lyon 1,

Bâtiment Forel (403)

43 Bd 11 Novembre 1918,

F-69622 Villeurbanne Cedex, France.

Tél : 0033 (0)4 72432945

Fax : 0033 (0)4 72431523

E-mail : foulquier@univ-lyon1.fr 
1 Key words: DOC, dissolved oxygen, aquifer sediment respiration, groundwater, vadose zone, stormwater infiltration

Abstract:

Decreases in dissolved organic carbon (DOC) and dissolved oxygen (DO) with increasing depth below the groundwater table are often considered as evidence for aerobic respiration; however they may reflect mixing of infiltrating water and groundwater. We found that groundwater DOC concentration was on average $0.3 \mathrm{mg} \mathrm{C}^{-1}$ higher and DO concentration $1.5 \mathrm{mg} \mathrm{O}_{2} \mathrm{l}^{-1}$ lower at recharge sites replenished with stormwater than at reference sites fed by direct infiltration of rain water from the land surface. Groundwater DOC increased and DO decreased with increasing vadose zone thickness (VZT) at both recharge and reference sites. There was no significant interaction between the effects of stormwater infiltration and VZT. Vertical changes in DOC and DO below the groundwater table at recharge sites could account for by simple mixing of infiltrating stormwater and groundwater. Moreover, aquifer sediment respiration (SR) was not significantly higher at recharge sites than at reference sites. However, slow filtration column experiments showed that SR increased significantly with an increasing supply of easily biodegradable DOC. We conclude that the observed reduction in DOC below the groundwater table at recharge sites was essentially due to water mixing rather than biological uptake because of the low biodegradability of DOC and short transit time of stormwater in the upper layers of groundwater. Our results highlight the need to distinguish between the effect of hydrological and biological processes on DOC and DO patterns below the groundwater before conclusions are made on the efficiency of groundwater in degrading surface-derived DOC. 
3 Groundwater ecosystem metabolism depends on transport of organic substances and electron

\section{Introduction}

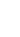

Groundwater ecosystem metabolism depends on transport of organic substances and electron acceptors from the surface (Chapelle 1993). The supply of dissolved organic carbon (DOC) to groundwater is usually low because the mineral soil horizons and the vadose zone intercept most of the DOC solubilized in the humic soil layer (Michalzik et al. 2001; Neff \& Asner 2001; Cannavo et al. 2004; Goldscheider et al. 2006) (Fig. 1). Weak DOC supply was shown to limit the rate of several biogeochemical processes in groundwater including aerobic respiration (Baker et al. 2000), nitrification (Holmes et al. 1994), and denitrification (Starr \& Gillham 1993; Siemens et al. 2003) and might also constrain the abundance and diversity of invertebrate assemblages (Datry et al. 2005). The residence time of water, environmental conditions (e.g. temperature, moisture, water flux) and the strength of attenuation processes in the soil and vadose zone interact in a complex way to control the amount of DOC reaching the groundwater table (Kalbitz et al. 2000). Several studies found an inverse relationship between the concentration of DOC in groundwater and vadose zone thickness (VZT), indicating vadose flowpaths with longer residence time exhibited more DOC retention (Pabich et al. 2001; Jardine et al. 2006; McMahon \& Chapelle 2008). The relationship between groundwater DOC concentration and the percolation rate of infiltrating water is unclear because higher water fluxes simultaneously reduce the transit time of water, dilute soil DOC solution, and potentially stimulate microbial activity in response to increased soil moisture (Amiel et al. 1990; Kalbitz et al. 2000).

The soil DOC leached to groundwater is retained onto aquifer sediments and consumed by microorganisms as groundwater moves either vertically or horizontally away from the 
1 recharge zone (Malard \& Hervant 1999). The concentration of dissolved oxygen (DO) in

2 groundwater decreases with decreasing VZT (McMahon \& Chapelle 2008) and shallow water-table aquifers typically exhibit higher vertical loss rates of DOC and DO than deep water-table aquifers (Malard \& Hervant 1999; Pabich et al. 2001). These are strong arguments in favor of a biological degradation of DOC in the upper groundwater layers. However, the losses of DOC and DO with increasing depth below the groundwater table or increasing distance from stream in downwelling areas cannot be taken in isolation as proof of aerobic respiration because they may be caused by other factors, including the mixing of distinct water sources and the spatio-temporal variability of the source and sink of DOC and DO (Rutherford \& Hynes 1987; Malard \& Hervant 1999; Sobczak \& Findlay 2002; Wassenaar \& Hendry 2007). For example, water mixing rather than denitrification was reported to explain the apparent change in nitrate concentration in a number of aquifers (Howard 1985; McMahon \& Bohlke 1996; Pinay et al. 1998). The significance of water mixing in generating declining gradients of DOC and DO is more likely to be enhanced at sites where groundwater is being rapidly recharged, either naturally or artificially, with surface water. Indeed, high recharge rates generate pronounced variation in the proportion of infiltrating water with increasing depth below the water table (Foulquier et al. 2009). In addition, they increase groundwater flow velocity, thereby limiting the biological uptake of DOC per distance unit.

The present study aimed to disentangle the effect of water mixing and biological uptake on spatial variation in the concentrations of DOC and DO at the water table region of an aquifer artificially recharged with stormwater. Measurements were conducted at recharge sites fed artificially with stormwater and reference sites fed exclusively by the natural infiltration of rainwater. We hypothesized that the reduction in DOC and DO concentration with increasing depth below the groundwater table at sites recharged with stormwater reflected 
water mixing rather than an in situ biological uptake of DOC. First, we tested the influence of VZT and recharge by measuring DOC and DO concentrations in groundwater beneath a range of VZTs at multiple recharge and reference sites. Second, a mixing model was used to determine whether vertical gradients of DOC and DO at recharge sites could be accounted for by a simple mixing of infiltrating stormwater and groundwater. Third, we examined differences in aquifer sediment respiration (SR) among recharge and reference sites and evaluated the biodegradability of DOC leached to groundwater by comparing SR measured in the field with that obtained in the laboratory with a control supply of easily biodegradable DOC.

\section{Material and methods}

Study sites

Study sites were located in the eastern aquifer of the Lyon metropolitan area, France (Fig. 2A). The aquifer (catchment area: $314 \mathrm{~km}^{2}$ ) consisted of 3 corridors separated by moraine hills of low hydraulic conductivity $\left(10^{-5}-10^{-8} \mathrm{~m} \mathrm{~s}^{-1}\right)$ (BURGEAP 2001; Datry 2003a). Aquifer corridors consisted of highly permeable glaciofluvial sediments (hydraulic conductivity: $10^{-3}$ $10^{-2} \mathrm{~m} \mathrm{~s}^{-1}$ ) and were drained by the Rhône River. The glaciofluvial deposit consisted of extremely heterogeneous sediments containing on average $1.2 \pm 0.7 \%$ of silt and clay (grain size $<0.08 \mathrm{~mm}), 23.5 \pm 5.1 \%$ of sand $(2-5 \mathrm{~mm}), 10.3 \pm 3.4 \%$ of gravel $(2-5 \mathrm{~mm})$, and $65.1 \pm$ $6.6 \%$ of pebble (> $5 \mathrm{~mm}$ ) (Malard et al. 2005). The aquifer was artificially recharged with stormwater at multiple locations to compensate for reduced natural recharge caused by the sealing due to urban surfaces. Artificial groundwater recharge with stormwater represented at 
1 least $10 \%$ of the annual flux of groundwater which was estimated at 69.1 million $\mathrm{m}^{3}$ (Giry

2 1997; Foulquier et al. 2009).

3

$4 \quad$ Monitoring sites

5 Twenty one sites were selected with a VZT ranging from 1.7 to $28.2 \mathrm{~m}$ (Fig. 2A). Twelve 6 recharge sites were in groundwater areas artificially recharged by stormwater infiltration 7 basins, and 9 reference sites in groundwater areas fed exclusively by direct infiltration of rain water from the land surface. The stormwater infiltration basins rapidly infiltrate $(<2$ days $)$ large quantities of runoff water collected during rainfall events from residential, commercial and/or industrial catchments into the aquifer (Barraud et al. 2002). Catchment areas and surface areas of the infiltration basins ranged from 2.5 to 285 ha and 0.08 to 1 ha, respectively (Table 1). The annual groundwater recharge below each stormwater system was estimated as follows:

$$
\text { Groundwater recharge }\left(\mathrm{m}^{3} \text { of stormwater } \mathrm{m}^{-2}\right)=\mathrm{P} \times \mathrm{RC} \times \mathrm{CA}_{\mathrm{IB}} / \mathrm{SA}_{\mathrm{IB}}
$$
where:

$\mathrm{P}(\mathrm{m})$ : annual precipitation $(0.835 \mathrm{~m} \pm 0.125 \mathrm{~m} ; \mathrm{n}=38$ years, $1970-2007)$ $\mathrm{RC}(\%)$ : runoff coefficient on urban catchment $(0.35)$ $\mathrm{CA}_{\mathrm{IB}}$ : catchment area of the infiltration basin $\left(\mathrm{m}^{2}\right)$ $\mathrm{SA}_{\mathrm{IB}}\left(\mathrm{m}^{2}\right)$ : surface area of the infiltration basin

The annual groundwater recharge below stormwater basins averaged $89 \pm 56 \mathrm{~m}^{3}$ of stormwater $\mathrm{m}^{-2}$ ( $\mathrm{n}=11$ basins) (Table 1$)$. For comparison, the annual groundwater recharge at reference site was estimated at $0.24 \mathrm{~m}^{3}$ of rainwater $\mathrm{m}^{-2}$ (i.e. $29 \%$ of annual precipitation) (BURGEAP 1995). All recharge and reference sites were equipped with monitoring wells 
with a perforated casing intersecting the first 5 meters below the groundwater table. At recharge sites, monitoring wells were in the immediate downstream vicinity of infiltration basins in order to intersect the stormwater plume flowing into groundwater.

\section{Well-cluster sites}

Recharge sites 1 and 2 were equipped with one cluster of 5 wells that were successively installed at depths of 1, 2, 3, 4 and $5 \mathrm{~m}$ below the groundwater table (Fig. 2B). At each site, the wells were located downstream of the infiltration basin and intersected the groundwater zone that was artificially recharged with stormwater. They were installed with an engineoperated hammer and were separated from each other by a distance of less than $2 \mathrm{~m}$ (Fig. 2B). The well casings were made of PVC or transparent Plexiglas ${ }^{\circledR}$ (inner diameter: $6 \mathrm{~cm}$ ) and were screened at their lower end over a height of only $0.5 \mathrm{~m}$ (Datry et al. 2003b; Foulquier et al. 2009).

Sites 3 to 5 were instrumented with 6 clusters of 5 wells that were successively installed at depths of 10, 30, 50, 70 and $90 \mathrm{~cm}$ below the groundwater table. At each site, three replicate well clusters were located upstream of the infiltration basin and three other replicate clusters were located in the immediate downstream vicinity of the basin. The upstream well clusters intersecting the groundwater zone that was not recharged with stormwater were used as reference sites while the downstream well clusters were used as recharge sites because they intersected the stormwater plume induced by the infiltration basins. Distances between the 3 replicate clusters did not exceed $10 \mathrm{~m}$ and wells within each replicate cluster were separated from each other by a distance of $0.5 \mathrm{~m}$. All wells were constructed of $3.8 \mathrm{~cm}$ inner diameter steel pipe with a screen of $13 \mathrm{~cm}$ in height (hole diameter: $0.5 \mathrm{~cm}$ ) at their lower ends. They were installed at the desired depths using a vibrating electric-powered hammer. 
Groundwater samples were collected from the 21 monitoring sites on four occasions (October 2001 and April, June and October 2002) to test for the effect of VZT and recharge with stormwater on the concentrations of DOC and DO in groundwater. Groundwater was collected at a depth of $1 \mathrm{~m}$ below the water table by pumping each well with a pneumatic piston pump equipped with 2 inflatable packers (discharge rate $\sim 101 \mathrm{~min}^{-1}$ ) (UWITEC Company, Mondsee, Austria). The first 50L of pumped water were discarded as rinse to ensure purging at least 3 times the well volume. We checked that specific conductance and

DO stabilized during well purging. After well purging, water was collected in 0.1-L burned glass bottles for the determination of DOC and DO was measured with an $\mathrm{O}_{2}$ meter (WTW OXI 330 meter, Weilheim, Germany) whose readings had been previously checked with the Winkler method. Water samples were stored at $4{ }^{\circ} \mathrm{C}$, brought within $4 \mathrm{~h}$ to the laboratory, and filtered through a $0.45 \mu \mathrm{m}$ membrane filter. Depth of the water table was measured in each well with a contact gauge (KL 010, OTT Messtechnik, Kempten, Germany).

DOC was determined using a carbon analyser (multi N / C ${ }^{\circledR} 3100$, Analytik Jena, Jena, Germany) based on thermocatalytic oxidation $\left(850{ }^{\circ} \mathrm{C}\right)$ of organic carbon and infrared detection of $\mathrm{CO}_{2}$. We used an automatic selection outlier method in which repeated injection of the same water samples was carried out until the coefficient of variation between any 2 injections was less than $2 \%$. The reproducibility of measurements calculated from repeated analyses of in-house standard (K-Phtalate solution, $1 \mathrm{mg} \mathrm{C}^{-1}$ ) was better than $\pm 0.05 \mathrm{mg} \mathrm{C}^{-1}$ $(1 \sigma)$ 
2 Changes in the concentration of DOC, DO, and chloride $\left(\mathrm{Cl}^{-}\right)$and specific conductance at depth below the water table were determined by collecting groundwater from well clusters on 3 rainfall events (October 2003, 2004 and 2005) and 3 dry-weather periods (October 2003, 2004 and 2005) at site 1, 3 rainfall events (November 2001 and March and June 2002) and 3 dry-weather periods (November 2001 and March and November 2002) at site 2, and one rainfall event at sites 3-5 (September 2006). Chloride and specific conductance were used as tracers to detect depth variation in the relative proportion of stormwater into groundwater because $\mathrm{Cl}^{-}$concentration and specific conductance of stormwater (ca $5 \mathrm{mg} \mathrm{Cl}^{-} \mathrm{l}^{-1}, 100 \mu \mathrm{S} \mathrm{cm}^{-}$ ${ }^{1}$ ) were much lower than those of groundwater (ca $22 \mathrm{mg} \mathrm{Cl}^{-}{ }^{-1},>500 \mu \mathrm{S} \mathrm{cm}^{-1}$ ). Chloride was determined by ion chromatography on water samples collected in polypropylene bottles. Specific conductance was measured in the field with a portable meter (WTW LF 330, Weilheim, Germany). The groundwater sampling procedure at sites 1 and 2 was the same as those described above. At sites 3 to 5, groundwater was pumped from the 6 well clusters with a suction piston pump (discharge rate: $101 \mathrm{~min}^{-1}$ ). The first $10 \mathrm{~L}$ of pumped water were discarded as rinse to ensure purging at least 3 times the well volume. Samples of stormwater were collected in the infiltration basins.

Concentration of DO in groundwater was recorded at 1-hr intervals for one year in well clusters at sites 1 and 2 to determine differences in oxygen depth profile among multiple rainfall events. An YSI 600 XLM multiparameter logger (Yellow Springs Instrument Co., Yellow Springs, Ohio) equipped with three probes measuring specific conductance, temperature and DO was positioned at screen depth in each well. Loggers were transported to the laboratory every 15 to 21 days for data transfer, data examination, probe maintenance and calibration. On several occasions we checked that measurements provided by the loggers were 
1 similar to those made on groundwater samples collected from the wells. Rainfall and air temperature data (1-hr intervals) for sites 1 and 2 were obtained from the nearest station of the Meteorological Survey of the city of Lyon.

Effect of recharge and depth below groundwater table on SR and sedimentary organic carbon

Aquifer sediment was collected from upstream and downstream well clusters at sites 3 to 5 during one rainfall event ( $\mathrm{n}=90$ samples) to test for the effect of recharge and depth below the groundwater table on sediment respiration (SR) and sedimentary organic carbon (SOC).

Sediment for respiration and SOC measurements was obtained by pumping because of the difficulty in recovering uncontaminated sediment cores at depth into this glaciofluvial aquifer (Malard et al. 2005). A mixture of water and sediment was extracted using a hand piston pump from each well (UWITEC Company, Mondsee, Austria). After sediment settling, at least $0.5 \mathrm{~L}$ of sediment was collected in polypropylene containers that were stored at $\sim 20{ }^{\circ} \mathrm{C}$ and brought within $4 \mathrm{~h}$ to the laboratory for analysis. The sediment was sieved wet through a 1-mm sieve and respiration was measured using the slurry technique (Furutani et al. 1984). About $10 \mathrm{~g}$ of wet sediment with $5 \mathrm{~mL}$ of groundwater collected in the wells were placed in $150 \mathrm{~mL}$ flasks. The samples were incubated under aerobiosis at $20{ }^{\circ} \mathrm{C}$, in the dark under a gentle shaking. At $\mathrm{t}=3 \mathrm{~h}$ and $\mathrm{t}=6 \mathrm{~h}, \mathrm{CO}_{2}$ gas was collected and then measured by gas chromatography on a MTI 200 microcatharometer (Agilent, Santa Clara, CA, USA). Dry weights of sediment were determined after drying at $60{ }^{\circ} \mathrm{C}$ and $\mathrm{SR}$ was expressed as ng of $\mathrm{CO}_{2} \mathrm{~g}^{-1}$ sediment dry weight (DW) $\mathrm{h}^{-1}$.

SOC was measured on replicate samples of $0.25 \mathrm{~g}$ that were placed in pre-combusted ceramic boats, dried at $50{ }^{\circ} \mathrm{C}$ and treated with $2 \mathrm{M} \mathrm{HCl}$ to remove inorganic carbon. Acid treatment consisted of repeated additions of small quantities of acid (up to $400 \mu \mathrm{L}$ ) with the samples 
1 being dried in a warming oven at $50{ }^{\circ} \mathrm{C}$ between each acid addition. The incremental addition

2 of acid continued until there was no visual evidence of effervescence. The organic carbon

3 content of sediment was then determined using a carbon analyser (multi N / C ${ }^{\circledR} 3100$,

4 Analytik Jena, Jena, Germany) based on thermocatalytic oxidation $\left(900{ }^{\circ} \mathrm{C}\right)$ of organic carbon

5 and infrared detection of $\mathrm{CO}_{2}$. Replicate sediment samples were analyzed until the coefficient

6 of variation between any 2 replicate samples was less than $10 \%$. The reproducibility of

7 measurements calculated from repeated measurements of calcite powder $\left(4.2 \mathrm{mg} \mathrm{CaCO}_{3} ; 120\right.$

$\left.8 \mathrm{~g} \mathrm{C} \mathrm{kg}^{-1}\right)$ was better than $\pm 26.5 \mu \mathrm{g} \mathrm{C}(1 \sigma)$.

Sediment respiration under controlled supply of BDOC

Slow filtration column experiments were conducted to assess the biodegradability of DOC leached to groundwater by comparing SR measured under field condition with that obtained

under controlled supply of BDOC. In addition, they enabled to test our ability to detect differences in SR in response to DOC enrichment despite sediment disturbance caused by sediment collection and sieving. Columns had an inner diameter of $10 \mathrm{~cm}$ and consisted of two experimental modules (10 $\mathrm{cm}$ high) topped by a third module of $5 \mathrm{~cm}$ in height (Mermillod-Blondin et al. 2005) (Fig. 3). They were filled with inert gravel and fresh sand to a height of $15 \mathrm{~cm}$. About $10 \mathrm{~cm}$ of water was left above the sediment surface. Gravels (grain size: $5-8 \mathrm{~mm}$ ) were cleaned with deionized water and dried at $60^{\circ} \mathrm{C}$. Fresh sand (grain size $100-1000 \mu \mathrm{m}$ ) was collected at a depth of $1 \mathrm{~m}$ below the bed of a gravel pit intersecting the water table of the glaciofuvial aquifer using the Bou-Rouch method (Bou \& Rouch 1967). Masses of gravel $(500 \mathrm{~g}, 500 \mathrm{~g}$ and $400 \mathrm{~g})$ and sand $(150 \mathrm{~g}, 150 \mathrm{~g}$ and $120 \mathrm{~g})$ were alternately introduced into the columns to obtain a heterogeneous porous media. 
1 Experiments were performed at constant temperature $\left(15 \pm 0.5^{\circ} \mathrm{C}\right)$ in the dark. The columns

2 were supplied from the top with reconstituted water $\left(96 \mathrm{mg} \mathrm{NaHCO} \mathrm{N}^{-1}, 39.4 \mathrm{mg} \mathrm{CaSO}_{4}\right.$

$32 \mathrm{H}_{2} \mathrm{O} \mathrm{l}^{-1}, 60 \mathrm{mg} \mathrm{MgSO}_{4} 7 \mathrm{H}_{2} \mathrm{Ol}^{-1}$ and $\left.4 \mathrm{mg} \mathrm{KCl} \mathrm{l}^{-1}, 19 \mathrm{mg} \mathrm{Ca} \mathrm{NO}_{3}\right)_{2} 4 \mathrm{H}_{2} \mathrm{O} \mathrm{l}^{-1}$, US EPA 1991)

4 using a peristaltic pump controlling a constant infiltration flow rate of $2 \mathrm{ml} \mathrm{min}^{-1}$. This flow

5 rate corresponded to the average groundwater recharge rate estimated at recharge sites.

6 Columns were operated as fully saturated to mimic moisture conditions in groundwater.

7 Supplied water was aerated to maintain concentrations of DO between 8.5 and $9.5 \mathrm{mg} \mathrm{l}^{-1}$ at

8 the inlet of the columns throughout the experiment. Three concentrations of sodium acetate

(i.e. $0.5 \mathrm{mg}, 1.5 \mathrm{mg}$ and $2.5 \mathrm{mg} \mathrm{C}-\mathrm{NaCH}_{3} \mathrm{COOH} \mathrm{l}^{-1}$ ), an easily biodegradable form of DOC, were applied to the columns with three replicate columns per concentration. Water sampling for DOC determination and oxygen measurements were made at four depths $(5 \mathrm{~cm}$ above the sediment surface, and 1, 5 and $10 \mathrm{~cm}$ below the sediment surface) by means of lateral water derivation outlets on days $6,10,14,18,22$ and 26 after the start of the experiments. For DO measurements, an oxygen micro-sensor probe (Unisense, Aarhus, Denmark) was directly connected to the lateral water derivation, thereby preventing any contact with atmospheric oxygen. On day 26 , the columns were dismantled and 3 sediment layers $(0-2,4-6$ and $9-11 \mathrm{~cm}$ below the sediment surface) were collected for the determination of SR and SOC. Analytical procedures for these 2 parameters were the same as those described above.

\section{Data analysis}

Linear regression analyses were performed to evaluate the relationships between VZT and concentrations of DOC and DO in groundwater. We used the average concentrations of DOC and DO from groundwater samples collected over the 4 sampling dates at 21 monitoring sites to avoid a pseudoreplication effect (i.e. unjustified increase in the degree of freedom). 
1 Analysis of covariance (ANCOVA) was used to determine whether the relationships differed

2 between recharge and reference sites. The design was a 2 (i.e. recharge versus reference sites) by 1 (i.e. VZT in $\mathrm{m}$ ) analysis.

A two-end member mixing model based on measured concentrations of chloride was used to:

(i) determine vertical change in the proportion of inflow stormwater in groundwater at recharge sites and (ii) to test whether the observed vertical changes in DOC and DO below the groundwater table could be accounted for by a simple mixing of water sources. Water sampled at each depth below the groundwater table during rainfall events was assumed to be a mix of pre-event groundwater and inflow stormwater infiltrating through the vadose zone. The relative proportion at depth $\mathrm{x}$ of water from depth $\mathrm{x}-1$ was calculated using the following formula:

$$
\mathrm{f}_{\mathrm{x}-1}=\left(\mathrm{C}_{\mathrm{x}}-\mathrm{Cg}_{\mathrm{x}}\right) /\left(\mathrm{C}_{\mathrm{x}-1}-\mathrm{Cg}_{\mathrm{x}}\right)
$$

where $\mathrm{f}_{\mathrm{x}-1}$ was the proportion at depth $\mathrm{x}$ of water from depth $\mathrm{x}-1$, and $\mathrm{C}_{\mathrm{x}}, \mathrm{Cg}_{\mathrm{x}}$ and $\mathrm{C}_{\mathrm{x}-1}$ represented the chloride concentrations of post-event groundwater, pre-event groundwater, and water collected at depth $\mathrm{x}-1$, respectively. Chloride was used as a conservative tracer (Triska et al. 1993). The proportion $\mathrm{f}_{\mathrm{x}-1}$ was used to calculate the concentrations of DOC and DO at each depth under the assumption of a simple mixing of water sources. Concentrations in upstream well clusters (sites 3 to 5) and groundwater collected during dry weather periods (sites 1 and 2) were used as pre-event groundwater concentrations. Concentrations of DOC and DO in stormwater collected in the infiltration basins were used as input concentrations in the model for calculating DOC and DO concentrations in the uppermost layer of groundwater. Calculated concentrations were plotted against measured concentrations and were compared using a Wilcoxon paired test. In order to test the validity of our mixing model, we checked 
that the calculated/measured ratio of specific conductance, which was also expected to behave as a conservative tracer, did not significantly differ from 1 .

We used continuous measurements of DO at sites 1 and 2 to examine differences in the vertical gradient of DO between cold and warm seasons. Warm and cold seasons corresponded respectively to months with higher and lower mean air temperature than the annual air temperature.

Analysis of variances (ANOVA) was used to test for the effect of recharge and depth below the water table on SR and SOC using data collected at well cluster sites 3 to 5 (n=90 wells). A nested design with sites, recharge nested in sites and depth as main effects was used in order to avoid confounding between-site variation with variation induced by recharge. The interactions between depth and recharge nested in sites as well as between depth and sites were also tested. ANOVA was performed to test for the effect of an increasing supply of BDOC on SR and SOC using data from the slow filtration column experiments. The design was a 3 (BDOC concentrations of $0.5,1.5$, and $2.5 \mathrm{mg} \mathrm{C}^{-1}$ ) by 3 (depths of 1,5 and $10 \mathrm{~cm}$ below the sediment surface) analysis. We examined the relationship between SR and the removal rate of DOC and DO in the slow filtration columns. The removal rate in each sediment layer (i.e. 0-2, 4-6 and 9-11 $\mathrm{cm}$ below the sediment surface) was calculated using data obtained on day 26 of the experiments as follows:

$$
\mathrm{RR}=\left(\Delta_{\mathrm{C}} \times \mathrm{Q}\right) /(\mathrm{V} \times \mathrm{P})
$$

Where:

RR: Removal rate of DOC and DO in $\mathrm{mg}^{-1}$ sediment $\mathrm{h}^{-1}$ $\Delta_{\mathrm{C}}$ : Difference in DOC or DO concentration $\left(\mathrm{mg} \mathrm{l}^{-1}\right)$ between 2 consecutive depths 
Q: water discharge $\left(1 \mathrm{~h}^{-1}\right)$ through the sediment layer

$\mathrm{V}$ : volume of the sediment layer (l)

P: porosity

Statistical analyses were performed using R ( $\mathrm{R}$ Development Core team 2006) and the Statistica $6^{\circledR}$ software package (Statsoft Inc., Tulsa, Oklahoma, USA). Significance for all statistical tests was accepted at $\alpha<0.05$.

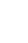

\section{Results}

\section{Effect of VZT and recharge on DOC and DO concentrations}

Groundwater DOC concentration varied from 0.1 to $3.1 \mathrm{mg} \mathrm{C}^{-1}$ and averaged $1 \pm 0.6 \mathrm{mg} \mathrm{C}^{-}$ ${ }^{1}(n=228)$, whereas that of stormwater averaged $4.6 \pm 1.9(n=34$; range: $2.5-11)$. DOC was negatively correlated and DO was positively correlated with VZT at both reference and recharge sites (Fig. 4). DOC was significantly higher $(\mathrm{p}=0.0107)$ and DO was significantly lower $(\mathrm{p}=0.0429)$ at recharge sites than at reference sites (Fig. 4, Tables $2 \& 3$ ). The increase in DOC and decrease in DO averaged $0.3 \mathrm{mg} \mathrm{C}^{-1}$ and $1.51 \mathrm{mg} \mathrm{O}_{2} \mathrm{l}^{-1}$, respectively. Near anoxic conditions (i.e. DO $<1 \mathrm{mg} \mathrm{O}_{2} \mathrm{l}^{-1}$ ) occurred at only 2 out of 11 recharge sites. The slopes of the regressions between VZT and DOC and DO concentrations did not differ between reference and recharge sites, indicating that the effect of recharge did not depend upon VZT. 
1 DOC decreased with increasing depth below the groundwater table but vertical gradients were

2 typically more pronounced at recharge sites 1,2 and 3 characterized by a distinct vertical reduction in the proportion of infiltrating stormwater (Fig. 5, Table 3). There was almost no variation in DOC concentration with depth at sites 4 and 5 , which showed little vertical change in the proportion of infiltrating stormwater. Wilcoxon matched pairs test indicated no difference $(n=72, p=0.13)$ between measured values of specific conductance and those calculated with the mixing model based on chloride concentrations (Fig. 6). There were also no differences ( $p>0.05)$ between calculated and measured concentrations of DOC at sites 1 and 3 (Figs $5 \& 6$ ). At site 2, measured concentrations of DOC were significantly lower than calculated concentrations $(n=12 ; \mathrm{p}=0.03)$ but the difference was no longer statistically significant $(n=9, p=0.17)$ when data at depth of $1 \mathrm{~m}$ below the groundwater table were excluded from the analysis. Vertical changes in DO below the groundwater table at recharge sites could also be accounted for by a simple mixing of infiltrating stormwater and groundwater (Figs $5 \&$ 6). At sites 2, 3, 4 and 5 measured concentrations of DO did not significantly differ $(\mathrm{p}>0.05)$ from calculated concentrations. At site 1 , measured concentrations of DO were significantly lower than calculated concentrations $(n=15, p=$ $0.047)$ but the difference was no longer statistically significant $(\mathrm{n}=12, \mathrm{p}=0.21)$ when data at depth of $1 \mathrm{~m}$ below the groundwater were excluded from the analysis. Vertical profiles of DO at sites 1 and 2 exhibited a clear seasonal shift (Fig. 7), although DOC concentration always decreased with depth during recharge events (sites 1 and 2 in Fig. 5). DO concentration decreased with depth during cold recharge events (i.e. cold rains), whereas it increased during warm recharge events.

\section{Effect of recharge and depth below groundwater table on SR and SOC}


1 SR varied greatly among sites 3-5 but was not significantly higher in downstream well

2 clusters than in upstream well clusters nor did it decrease with increasing depth below the water table (Fig. 8, Table 3). A non significant effect $(\mathrm{p}=0.140)$ of groundwater recharge with stormwater on SR was observed although DOC was significantly higher $(\mathrm{p}<0.001)$ and DO was significantly lower $(\mathrm{p}<0.001)$ in downstream well clusters than in upstream well clusters (Table 3). SOC was significantly higher in downstream well clusters but there were no differences among depths (Table 3).

\section{Response of SR to DOC enrichment under controlled conditions}

SR increased significantly $(\mathrm{p}<0.001)$ with increasing BDOC supply and decreased with depth $(\mathrm{p}=0.014)$ (Fig. 9, Table 4). The increase in sediment respiration was typically more pronounced in the first $\mathrm{cm}$ of sediment. SR with a supply of BDOC ( $\mathrm{SR}=547 \pm 601 \mathrm{ng} \mathrm{CO} \mathrm{g}^{-1}$ dry sediment weight $\mathrm{h}^{-1}$ ) was on average 4.3 times higher than that measured under field conditions ( $\mathrm{SR}=127 \pm 206 \mathrm{ng} \mathrm{CO}_{2} \mathrm{~g}^{-1}$ dry sediment weight $\mathrm{h}^{-1}$ ). SR resulted in a steep decreasing gradient in the concentration of DOC and DO in the slow filtration columns. The removal rates (RR) of DOC and DO increased significantly with increasing BDOC supply and

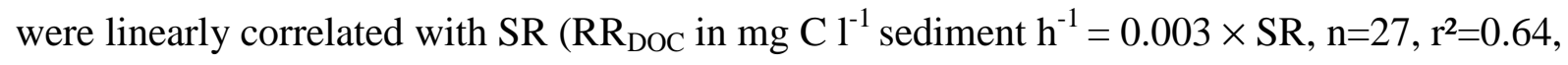
$\left.\mathrm{p}<0.001 ; \mathrm{RR}_{\mathrm{DO}}=0.006 \times \mathrm{SR}, \mathrm{n}=27, \mathrm{r}^{2}=0.72, \mathrm{p}<0.001\right)$ (Table 4). The molar ratio of consumed $\mathrm{O}_{2}$ to removed $\mathrm{C}$ equaled 0.65 and did not vary among depths $\left(\mathrm{RR}_{\mathrm{DO}}\right.$ in $\mathrm{mol} \mathrm{O}_{2} \mathrm{l}^{-1}$ sediment $\mathrm{h}^{-}$ $\left.{ }^{1}=0.65 \times \mathrm{RR}_{\mathrm{DOC}}, \mathrm{n}=27, \mathrm{r}^{2}=0.95, \mathrm{p}<0.001\right)$. SOC did not significantly increase $(\mathrm{p}=0.944)$ with increasing BDOC supply but it was significantly higher $(\mathrm{p}<0.001)$ in the first $\mathrm{cm}$ of sediment (Fig. 9, Table 4).

\section{Discussion}


Our finding that groundwater DOC concentration decreased and DO increased with increasing VZT corroborated the results of recent studies conducted in several aquifers of the United States (Pabich et al. 2001; McMahon \& Chapelle 2008). A longer residence time of water in the vadose zone enabled an increasing amount of soil-derived DOC to be removed from solution either by adsorption or respiration. The subsequent mineralization of the remaining soil DOC fraction leached to groundwater probably accounted for the observed positive relation between DO concentration and VZT (McMahon \& Chapelle 2008). The diffusion of oxygen through the vadose zone and into the saturated zone was another process that might have influenced DO concentration in groundwater. However, Neale et al. (2000) showed that the reaeration flux rate decreased with increasing VZT. The linear relationships between DOC and DO concentrations and VZT observed in this study differed from exponential relationships reported for several aquifers of the United States for which the reduction rate in DOC was much higher for VZT less than 2 to $3 \mathrm{~m}$ (Pabich et al. 2001; McMahon \& Chapelle 2008). This difference was essentially due to a lack of DOC measurements for VZT $<2 \mathrm{~m}$ because of the scarcity of shallow water-table sites in the glaciofluvial aquifer of the Lyon City.

The increase in groundwater DOC concentration at recharge sites was caused by localized infiltration of stormwater enriched in organic matter during runoff on urban catchments (Pitt et al. 1999). Stormwater also leached DOC as it percolated through the infiltration beds. Slow filtration column experiments showed that the concentration of DOC in stormwater could increase by 10 to $40 \mathrm{mg} \mathrm{Cl}^{-1}$ as it percolated through bed sediments of recharge sites 1 and 2 
1 (Datry et al. 2003c; Larmet 2007; Nogaro et al. 2007). Two distinct, albeit not mutually

exclusive, mechanisms could account for the observed reduction in groundwater DO at recharge sites. The first mechanism was the mineralization in groundwater of an excess of labile DOC brought by infiltrating water (Pabich et al. 2001). The second mechanism did not necessitate a supply of labile DOC but corresponded to groundwater recharge with stormwater that had been depleted of DO during its transit through the infiltration bed (Datry et al. 2003c, 2004; Foulquier et al. 2009). Both mechanisms could also explain why the effect of recharge on DOC and DO concentrations did not appear to depend on VZT. The first mechanism implies that an increased amount of labile DOC reached the groundwater at recharge sites but this amount and the resulting DO consumption in groundwater was controlled by VZT in the same way as at reference sites. The second mechanism implies that excess DOC leached to groundwater at recharge sites was poorly biodegradable and did not stimulate microbial respiration. In addition, replenishment of groundwater with oxygen-poor stormwater decreased DO concentration at all recharge sites independently of VZT.

\section{Significance of water mixing on vertical gradient of DOC and DO}

Results of the mixing model strongly indicated that decreasing gradients of DOC were essentially due to a decrease in the proportion of DOC-rich infiltrating water with increasing depth below the groundwater table. This was consistent with the lack of DOC attenuation with depth at recharge sites 4 and 5, which were characterized by a constant proportion of newly infiltrating stormwater at all depths. DOC concentration was not markedly affected by biological uptake or adsorption within the first meter below the groundwater table. Our conclusion that groundwater was not a sink of DOC was based on the assumption that the mixing model provided a reasonable estimate of concentrations expected if only mixing 
processes were important. This assumption was robust because the calculated/measured ratio of specific conductance that was expected to be conservative did not significantly differ from 1. Results of the mixing model also depended on our estimates of chloride, DOC and DO concentrations for each water source and depth. The only major uncertainty was the concentration of DOC and DO of infiltrating water reaching the uppermost layer of groundwater. The mixing model probably overestimated the attenuation of DOC and consumption of DO in the uppermost layer of groundwater because stormwater was assumed to reach groundwater with DOC and DO concentrations equaled to those measured in the infiltration basins. In any case, this uncertainty did not affect the model calculations at subsequent depths.

The mixing model satisfactorily explained vertical gradients of DO in recharge areas even in cases when declines in DOC were accompanied by a concomitant loss in DO. Moreover, we found that DO evolved independently of the DOC decline because it alternatively increased and decreased with depth during winter and summer rainfall events. This implied that DO gradients were controlled by the concentration of infiltrating water reaching the groundwater table rather than by in situ consumption of DO in groundwater. Datry et al. (2004) and Foulquier et al. (2009) suggested that the dynamics of DO in groundwater below stormwater infiltration basins might be strongly influenced by temperature-induced changes in the rate of oxygen consumption in infiltration beds. Summer warming of the bed probably stimulated microbial respiration, thereby leading to a downward flow of oxygen-poor stormwater. Datry et al. (2003c) and Nogaro et al. (2007) showed that oxygen uptake in filtration columns filled with sediment collected in infiltration beds at recharge sites 1 and 2 could lead to near anoxic conditions at a depth of only $5 \mathrm{~cm}$ below the water sediment interface. Reaeration of infiltrating water due to $\mathrm{O}_{2}$ diffusion in the vadose zone was probably minimal because the 
1 high stormwater infiltration rate (i.e. $0.0141 \mathrm{~m}^{-2} \mathrm{~s}^{-1}$ ) rapidly led to pore space saturation with

2 water (Refsgaard et al. 1991; Le Coustumer \& Barraud 2007; Goutaland et al. 2008).

3 Groundwater DO depletion below stormwater infiltration basins was reported in a number of

4 studies but the causal mechanisms remained unclear (Fischer et al. 2003). Determining the

5 relative significance of replenishment with deoxygenated but DOC-poor water and in situ DO

6 consumption due to a supply of labile DOC is of paramount importance because these two

7 processes may result in dissimilar changes in the rate of microbial terminal electron acceptor processes in groundwater (e.g. denitrification, iron reduction).

Effect of DOC supply on SR

The lack of stimulation of SR at recharge sites was congruent with our observation that the decrease in DOC and DO concentrations with depth essentially reflected mixing of infiltrating water and groundwater. Studies of biological activity along subsurface flowpaths in which DOC loss was observed provided equivocal results with some studies but not all reporting a concomitant decrease in SR, bacterial activity or abundance (Findlay et al. 1993; Marmonier et al. 1995; Ellis et al. 1998; Battin 2000, Craft et al. 2002; Sobczak \& Findlay 2002). Stormwater reaching groundwater was probably a source of low biodegradable DOC since slow filtration column experiments demonstrated that SR was extremely sensitive to an increase in BDOC supply. The increase in SR within slow filtration columns enabled an increasing quantity of dissolved acetate (up to $1 \mathrm{mg} \mathrm{C}^{-1}$ sediment $\mathrm{h}^{-1}$ ) to be almost totally removed within only $10 \mathrm{~cm}$ of sediment. Baker et al. (1999) found that acetate injected into hyporheic sediment of Rio Calaveras stream, New Mexico, with an initial concentration of 7.9 mg C $\mathrm{C}^{-1}$ stimulated aerobic and anaerobic respirations and was entirely consumed along flowpath length $<50 \mathrm{~cm}$. In the present study, the more labile fraction of DOC was likely to 
1 be intercepted in the soil and vadose zone, leaving only the refractory fraction to reach the underlying groundwater. Pabich et al. (2001) found that the DOC loss rate as a function of depth below groundwater table in Cape Cod, USA decreased with increasing VZT indicating that DOC was either less labile or sorbable under thicker vadose zones. The low DOC concentration $\left(<2 \mathrm{mg} \mathrm{Cl}^{-1}\right)$ and the lack of stimulation of SR in groundwater at recharge sites characterized by high stormwater infiltration rate and VZT $<3 \mathrm{~m}$ indicated that the soil and vadose zone were very efficient in retaining DOC either by mineralization or adsorption. The increase in sediment moisture associated with stormwater infiltration could stimulate microbial activity, thereby enhancing microbial degradation of DOC in the soil and vadose zone (Kalbitz et al. 2000; Marschner \& Kalbitz 2003). Amiel et al. (1990) pointed out that the biological degradation of sewage derived DOC in the vadose zone was more efficient under saturated conditions prevailing below infiltration ponds than under unsaturated conditions prevailing below land irrigated with wastewater effluent.

Adsorption of dissolved organic matter onto mineral particles, its retention by microbial extracellular polymeric substances and its assimilation into bacterial biomass might also contribute to reduce DOC concentration along groundwater flowpaths (Kaplan \& Newbold 2000). Unlike microbial respiration, these mechanisms were expected to result in a decreasing gradient of SOC with depth. SOC was significantly higher at recharge sites than at reference sites but it did not exhibit any decreasing trend with depth that might have indicated a preferential retention of DOC in the uppermost layers of groundwater. In slow filtration columns, the first $\mathrm{cm}$ of sediment which exhibited the highest removal rates of BDOC and DO also had a distinctively higher SOC concentration. SOC accumulation within this uppermost layer probably reflected a biological retention and/or assimilation of BDOC rather than a physical adsorption of BDOC onto mineral particles because our $\mathrm{C}$ to $\mathrm{O}_{2}$ molar ratio of 
10.65 effectively corresponded to values reported in the literature for microbial degradation of

2 BDOC (Bauerfind 1985; Pusch \& Schwoerbel 1994; Roy et al. 1999). Baker et al. (1999) did

not observe any acetate sorption onto aquifer sediment samples of Rio Calaveras that were incubated for $30 \mathrm{~min}$ in acetate solutions with concentrations ranging from 1 to $100 \mathrm{mg} \mathrm{C}^{-1}$.

Our conclusion that vertical gradient of DOC and DO at recharge sites was essentially due to water mixing might seem to contradict our interpretation of a positive relation between DO and VZT being caused by mineralization of DOC leached to groundwater at reference sites. Depending on the biodegradability of DOC leached to groundwater at recharge sites, the contact time of water with sediment in the upper layers of groundwater could be too short to result in a detectable decreasing trend in DOC and DO with depth. At site 1, the vertical velocity of stormwater in the upper layers of groundwater during rainfall events was found to average $7 \mathrm{~m} \mathrm{day}^{-1}$ based on phase difference between time series of specific conductance at multiple depths below the groundwater table (Foulquier et al. 2009). This vertical velocity was 10 times higher than that estimated at reference sites using a three-dimension model of groundwater flow in the glaciofluvial aquifer (Chastanet et al. 2008). Kalbitz et al. (2003) who conducted out 90-day liquid incubation experiments with DOC from diverse soil samples found a mean residence time of 3.3 to 8.9 days for the labile DOC pool and 0.3 to 12.5 years for the stable DOC pool.

Our results suggest that non retentive processes such as water mixing or differential residence time of water can lead us to over-estimate the ability of groundwater to act as a sink of DOC being transported through the vadose zone. They highlight the need for detailed studies of coupled hydrological and biogeochemical processes for determining the DOC retention capacity of the upper layers of groundwater. Current research in this glaciofluvial aquifer is 
examining the relationship between DOC composition as evaluated by excitation-emission fluorescence spectroscopy (Kalbitz et al. 2003) and SR in the upper layers of groundwater under different recharge conditions.

\section{Acknowledgements}

This study was conducted with the framework of the experimental observatory for urban hydrology (OTHU, http://www.graie.org/othu/). It was funded by the French National Research Agency (project ANR-05-ECOT-006; http://www.graie.org/ecopluies/), the french programme EC2CO-Cytrix from INSU/CNRS (project "NAPCOD"), the urban community of Lyon, and the Rhône-Alpes Region. We are indebted to G. Bouger, E. Malet, Y. Negrutiu, B. Volat, and F. Vallier for their most dedicated support with the field and laboratory work. We thank Ton Snelder and two anonymous reviewers for their comments that improved an earlier version of the manuscript.

\section{References}

Amiel AJ, Magaritz M, Ronen D et al (1990) Dissolved organic carbon in the unsaturated zone under land irrigated by wastewater effluent. Res J Water Pollut Control Fed 62:861866

Baker MA, Dahm CH, Valett HM (1999) Acetate retention and metabolism in the hyporheic zone of a mountain stream. Limnol Oceanogr 44:1530-1539

Baker MA, Valett HM, Dahm CN (2000) Organic carbon supply and metabolism in a shallow groundwater ecosystem. Ecology 81:3133-3148 
1 Barraud S, Gibert J, Winiarski $\mathrm{T}$ et al (2002) Implementation of a monitoring system to measure impact of stormwater runoff infiltration. Water Sci Technol 45:203-210

Battin TJ (2000) Hydrodynamics is a major determinant of streambed biofilm activity: from the sediment to reach scale. Limnol Oceanogr 45:1308-1319

Bauerfind S (1985) Degradation of phytoplankton detritus by bacteria : estimation of bacterial consumption and respiration in an oxygen chamber. Mar Ecol Prog Ser 21:27-36

Bou C, Rouch R (1967) Un nouveau champ de recherches sur la faune aquatique souterraine. CR Acad Sci Paris 265:369-370

BURGEAP (1995) Etude de la nappe de l'Est Lyonnais. Hydrogeological report, BURGEAP,

BURGEAP (2001) Etude hydrogéologique du secteur du bassin d'infiltration Django Lyon, France, available from: http://www.burgeap.fr Reinhardt à Chassieu 69. Hydrogeological report Ly.765/A.7302. BURGEAP, Lyon, France, available from: http://www.burgeap.fr

Cannavo P, Richaume A, Lafolie F (2004) Fate of nitrogen and carbon in the vadose zone: in situ and laboratory measurements of seasonal variations in aerobic respiratory and denitrifying activities. Soil Biol Biochem 36:463-478

Chapelle FH (1993) Groundwater microbiology and geochemistry. John Wiley and Sons, New York

Chastanet J, Kaskassian S, Côme J-M et al (2008) Transport de chaleur et température des nappes phréatiques à l'aplomb des bassins d'infiltration d'eau de ruissellement pluvial. Hydrogeological Report ANR-05-ECOT-006, BURGEAP, Lyon, France, available from http://www.graie.org/ecopluies/

Craft JA, Stanford JA, Pusch M (2002) Microbial respiration within a floodplain aquifer of a large gravel-bed river. Freshwat Biol 47:251-261 
1 Datry T (2003a) Urbanisation et qualité des nappes phréatiques: réponses des écosystèmes aquatiques souterrains aux pratiques d'infiltration d'eau pluviale. $\mathrm{PhD}$ thesis, University Lyon 1, Lyon, France

Datry T, Malard F, Niederreiter et al (2003b) Video-logging for examining biogenic structures in deep heterogeneous subsurface sediments. CR Biol 326: 589-597.

Datry T, Malard F, Vitry L et al (2003c) Solute dynamics in the bed of a stormwater infiltration basin. J Hydrol 273:217-233

Datry T, Malard F, Gibert J (2004) Dynamics of solutes and dissolved oxygen in shallow urban groundwater below a stormwater infiltration basin. Sci Total Environ 329:215-229

Datry T, Malard F, Gibert J (2005) Response of invertebrate assemblages to increased groundwater recharge rates in a phreatic aquifer. J N Am Benthol Soc 24:461-477

Ellis BK, Stanford JA, Ward JV (1998) Microbial assemblages and production in alluvial aquifers of the Flathead River, Montana, USA. J N Am Benthol Soc 17:382-402

Findlay S, Strayer D, Goumbala C et al (1993) Metabolism of streamwater dissolved organic carbon in the shallow hyporheic zone. Limnol Oceanogr 38:1493-1499

Fischer D, Charles EG, Baehr AL (2003) Effects of stormwater infiltration on quality of groundwater beneath retention and detention basins. J Environ Eng 129:464-471

Foulquier A, Malard F, Barraud S et al (2009) Thermal influence of urban groundwater recharge from stormwater basins. Hydrol Process 23:1701-1713

Furutani A, Rudd JW, Kelly CA (1984) A method for measuring the response of sediment microbial communities to environmental perturbations. Can J Microbiol 3011:1408-1414

Giry G (1997) Mise en place d'un suivi qualitatif et quantitatif de la nappe de l'est lyonnais. MS Thesis, Ecole Supérieure de l'Energie et des Matériaux, Orléans, France

Goldscheider N, Hunkeler D, Rossi P (2006) Review: microbial processes in pristine aquifers and an assessment of investigative methods. Hydrogeol J 14:926-941 
1 Goutaland D, Winiarski T, Dubé JS et al (2008) Hydrostratigraphic characterization of glaciofluvial deposits underlying an infiltration basin using ground penetrating radar. Vadose Zone J 7:194-207

Holmes RM, Fisher SG, Grimm NB (1994) Parafluvial nitrogen dynamics in a desert stream ecosystem. J N Am Benthol Soc 13:468-478

Howard KWF (1985) Denitrification in a major limestone aquifer. J Hydrol 76:265-280

Jardine PM, Mayes MA, Mulholland PJ et al (2006) Vadose zone flow and transport of dissolved organic carbon at multiple scales in humid regimes. Vadose Zone J 5:140-152

Kalbitz K, Solinger S, Park J-H et al (2000) Controls on the dynamics of dissolved organic matter in soils: a review. Soil Science 165:277-304

Kalbitz K, Schmerwitz J, Schwesig D et al (2003) Biodegradation of soil-derived dissolved organic matter as related to its properties. Geoderma 113:273-291

Kaplan LA, Newbold JD (2000) Surface and subsurface dissolved organic carbon. In: Gibert J, Danielopol D, Stanford JA (eds), Groundwater Ecology. Academic Press, San Diego, pp 237-258

Larmet H (2007) Mobilisation et transfert de Zn, Cd, Cu et des colloïdes bactériens dans les bassins d'infiltration d'eaux pluviales : influence des conditions hydrodynamiques. $\mathrm{PhD}$ Thesis, University Joseph Fourier, Grenoble, France

Le Coustumer S, Barraud S (2007) Long-term hydraulic and pollution retention performance of infiltration systems. Water Sci Technol 55:235-243

Malard F, Hervant F (1999) Oxygen supply and the adaptations of animals in groundwater. Freshwat Biol 41:1-30

Malard F, Datry T, Gibert J (2005) Subsurface sediment contamination during borehole drilling with an air-actuated down-hole hammer. J Contam Hydrol 79, 156-164 
1 Marmonier P, Fontvieille D, Gibert J et al (1995) Distribution of dissolved organic carbon and bacteria at the interface between the Rhône River and its alluvial aquifer. J N Am Benthol Soc $14: 382-392$

Marschner B, Kalbitz K (2003) Controls of bioavailability and biodegradability of dissolved organic matter in soils. Geoderma 113:211 -235

McMahon PB, Bohlke JK (1996) Denitrification and mixing in a stream-aquifer system: effects on nitrate loading to surface water. J Hydrol 1861:105-128.

McMahon PB, Chapelle FH (2008) Redox processes and water quality of selected principal aquifer systems. Ground Water 462:259-271

Mermillod-Blondin F, Mauclaire L, Montuelle B (2005) Use of slow filtration columns to assess oxygen respiration, consumption of dissolved organic carbon, nitrogen transformations, and microbial parameters in hyporheic sediments. Water Res 39:16871698

Michalzik B, Kalbitz K, Park JH et al (2001) Fluxes and concentrations of dissolved organic carbon and nitrogen - a synthesis for temperate forests. Biogeochemistry 52:173-205

Neale CN, Hughes JB, Ward CH (2000) Impacts of unsaturated zone properties on oxygen transport and aquifer reaeration. Ground Water 38:789-794

Neff JC, Asner GP (2001) Dissolved organic carbon in terrestrial ecosystems: synthesis and a model. Ecosystems 4:29-48

Nogaro G, Mermillod-Blondin F, Montuelle B et al (2007) Influence of a stormwater sediment deposit on microbial and biogeochemical processes in infiltration porous media. Sci Total Environ 377:334-348

Pabich WJ, Valiela I, Hemond HF (2001) Relationship between DOC concentration and vadose zone thickness and depth below the water table in groundwater of Cape Cod, U.S.A.. Biogeochemistry 553:247-268 
1 Pinay G, Ruffinoni C, Wondzell S et al (1998) Change in groundwater nitrate concentration in a large river floodplain: denitrification, uptake, or mixing? J N Am Benthol Soc 17:179189

Pitt R, Clark S, Field R (1999) Groundwater contamination potential from stormwater infiltration practices. Urban Water 1(3), 217-236.

Pusch M, Schwoerbel J (1994) Community respiration in hyporheic sediments of a mountain stream (Steina, Black Forest). Archiv Hydrobiol 130:33-52

R Development Core Team (2006) R: a language and environment for statistical computing. R Foundation for Statistical Computing: Vienna. http://www.R-project.org.

Refsgaard JC, Christensen TH, Ammentorp HC (1991) A model for oxygen transport and consumption in the unsaturated zone. J Hydrol 129:349-369

Roy SO, Packard TT, Berdalet E et al (1999) Impact of acetate, pyruvate, and physiological state on respiration and respiratory quotients in Pseudomonas nautica. Aquat Microb Ecol $17: 105-110$

Rutherford JE, Hynes HBN (1987) Dissolved organic carbon in streams and groundwater. Hydrobiologia 154:33-48

Siemens J, Haas M, Kaupenjohann M (2003) Dissolved organic matter induced denitrification in subsoils and aquifers? Geoderma 113:253-271

Sobczak WV, Findlay S (2002) Variation in bioavailability of dissolved organic carbon among stream hyporheic flowpaths. Ecology 83:3194-3209

Starr RC, Gillham RW (1993) Denitrification and organic carbon availability in two aquifers. Ground Water 31: 934-947

Triska F, Duff JH, Avanzino R (1993) The role of water exchange between a stream channel and its hyporheic zone in nitrogen cycling at the terrestrial-aquatic interface. Hydrobiologia 251:167-184 
1 US EPA (1991) Methods for measuring the acute toxicity of effluents and receiving waters to

2 freshwater and marine organisms. Report EPA/600/4-90/27, Fourth edition, U.S.

3 Environmental Protection Agency, Washington

$4 \quad$ Wassenaar LI, Hendry MJ (2007) Dynamics and stable isotope composition of gaseous and 5 dissolved oxygen. Ground Water 45:447-460

6 
2 Figure 1: Fate of DOC during infiltration of surface water in the soil, vadose zone and groundwater. Vertical change in DOC concentration below the groundwater table may either result from water mixing or biological uptake of DOC in groundwater.

Figure 2: A. Locations of recharge sites (stormwater infiltration basins) and reference sites. B. Cross sectional illustration of well clusters at site 1 to 5 .

Figure 3: Schematic diagram of a slow filtration column and description of the sampling procedure.

Figure 4: Relationships between the concentrations of dissolved organic carbon (DOC) and dissolved oxygen (DO) in groundwater and vadose zone thickness at reference sites (left panels) and recharge sites (right panels).

Figure 5: Changes at depth below the groundwater table in: 1) the relative proportion of stormwater into groundwater (left panels); 2) measured (black circles) and calculated (white circles) concentrations of dissolved organic carbon (DOC) (middle panels) and; 3) measured (black circles) and calculated (white circles) concentrations of dissolved oxygen (DO) (right panels). Horizontal bars show \pm 1 standard deviation for 3 rainfall events at sites 1 and 2 and 3 replicate wells at sites 3 to 5 .

Figure 6: Calculated values from the two-end member mixing model based on chloride concentrations versus measured values for specific conductance (Sp. Cond.), dissolved organic carbon (DOC), and dissolved oxygen (DO). Values $(n=72)$ were from all sites, 
dates and depths. White symbols correspond to the uppermost depth. The line indicates 1:1 equivalence relationships.

(1)

Figure 7: Vertical gradients of dissolved oxygen below the groundwater table at recharge sites 1 and 2 before (grey circles) and after (black circles) rainfall events during the warm (left panels) and cold (right panels) seasons. Horizontal bars show \pm 1 standard deviation for multiple rainfall events $(n=5$ warm events and 5 cold events at site $1 ; n=6$ warm and cold events at site 2).

Figure 8: Changes at depth below the groundwater table in sediment respiration (SR) and sedimentary organic carbon (SOC) in upstream (white square) and downstream (black circles) well clusters at sites 3 to 5 . Horizontal bars show \pm 1 standard deviation for 3 replicate wells.

Figure 9: Vertical gradients of sediment respiration (SR), sedimentary organic carbon (SOC), dissolved organic carbon (DOC) and dissolved oxygen (DO) at day 26 in slow filtration columns supplied with water containing 0.5 (upper panels), 1.5 (middle panels) and 2.5 (lower panels) mg C - sodium acetate $\mathrm{l}^{-1}$.

Table 1: Characteristics of recharge (below stormwater infiltration basins) and reference sites. Recharge at reference sites was derived only from the natural infiltration of rainwater $\left(0.24 \mathrm{~m}^{3} \mathrm{~m}^{-2}\right)$

Table 2: Results of analysis of covariance for testing the effect of recharge and vadose zone thickness (VZT) on the concentrations of dissolved organic carbon (DOC) and dissolved oxygen (DO). 
2 Table 3: Results of nested analysis of variance for testing the effect of recharge and depth

3 below the groundwater table on the concentrations of dissolved organic carbon (DOC) and

4 dissolved oxygen (DO) in groundwater, sediment respiration (SR) and sedimentary

$5 \quad$ organic carbon (SOC).

6

$7 \quad$ Table 4: Results of analysis of variance for testing the effect of an increasing supply of labile

8 dissolved organic carbon (DOC as sodium acetate) and depth on removal rates of

9 dissolved organic carbon (RR-DOC) and dissolved oxygen (RR-DO) in slow filtration columns, sediment respiration (SR) and sedimentary organic carbon (SOC). 
Figure 1: Foulquier et al.

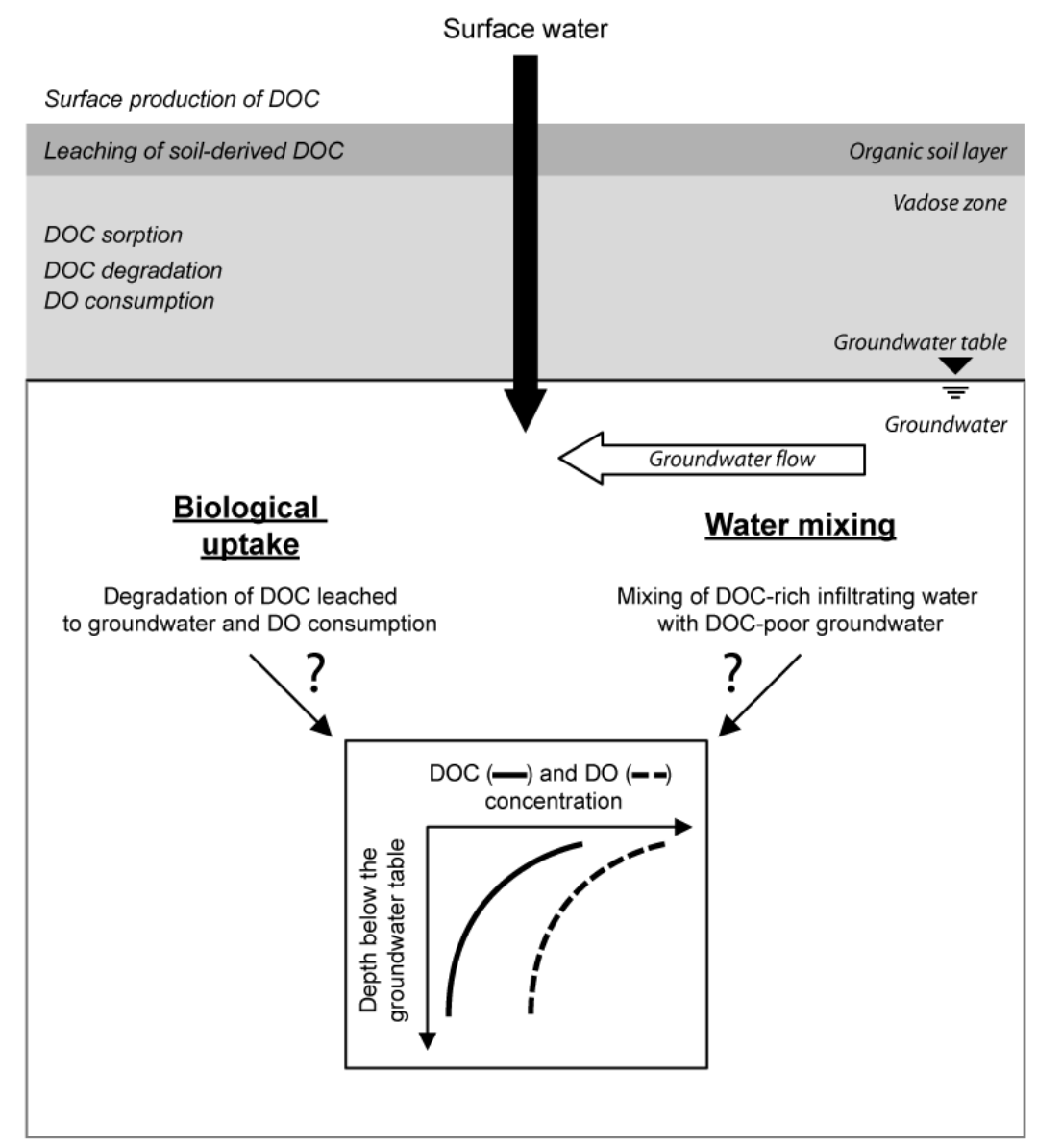

Figure 1: Fate of DOC during infiltration of surface water in the soil, vadose zone and groundwater. Vertical change in DOC concentration below the groundwater table may either result from water mixing or biological uptake of DOC in groundwater. 
Figure 2: Foulquier et al.

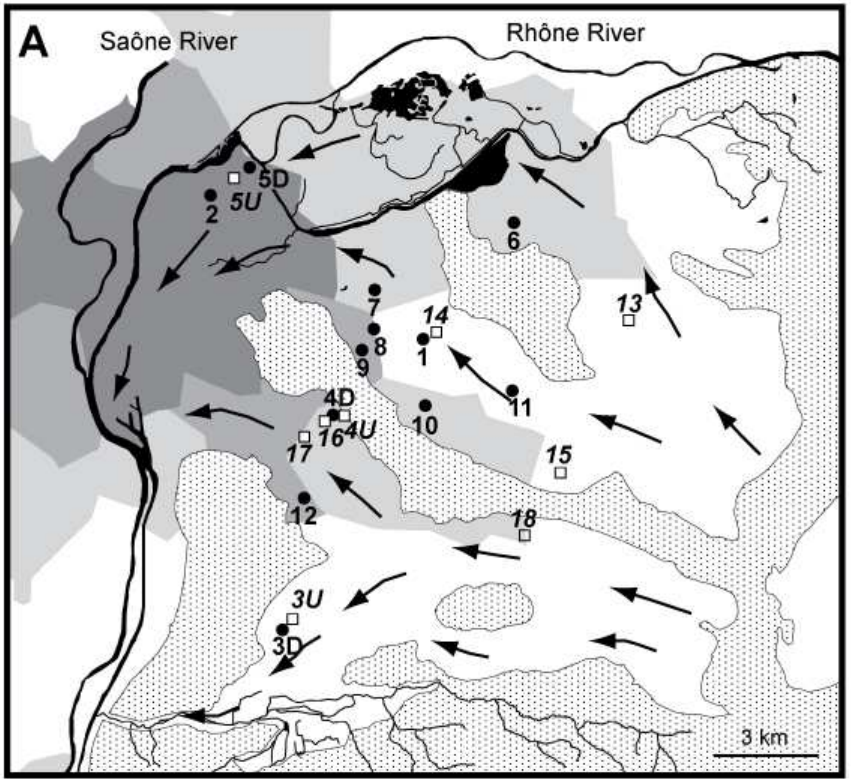

B Sites $1 \& 2$

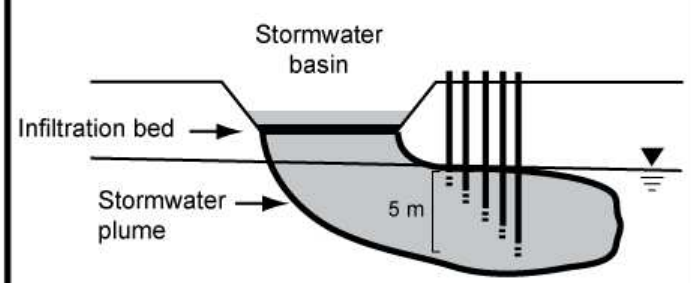

Sites $3,4 \& 5$

Upstream replicate Downstream replicate well clusters $(\times 3) \quad$ well clusters $(\times 3)$

Population density (inhabitants $/ \mathrm{km}^{2}$ )

$\square$ 100-1,000 $\square$ 1,000-3,000 $\square 3,000-6,000 \square 6,000-10,000$

Moraine hill (glacial till)

$\longrightarrow$ Groundwater flow direction

Recharge site

$\square \quad$ Reference site

Figure 2: A. Locations of recharge sites (stormwater infiltration basins) and reference sites.

B. Cross sectional illustration of well clusters at site 1 to 5 . 
Figure 3: Foulquier et al.

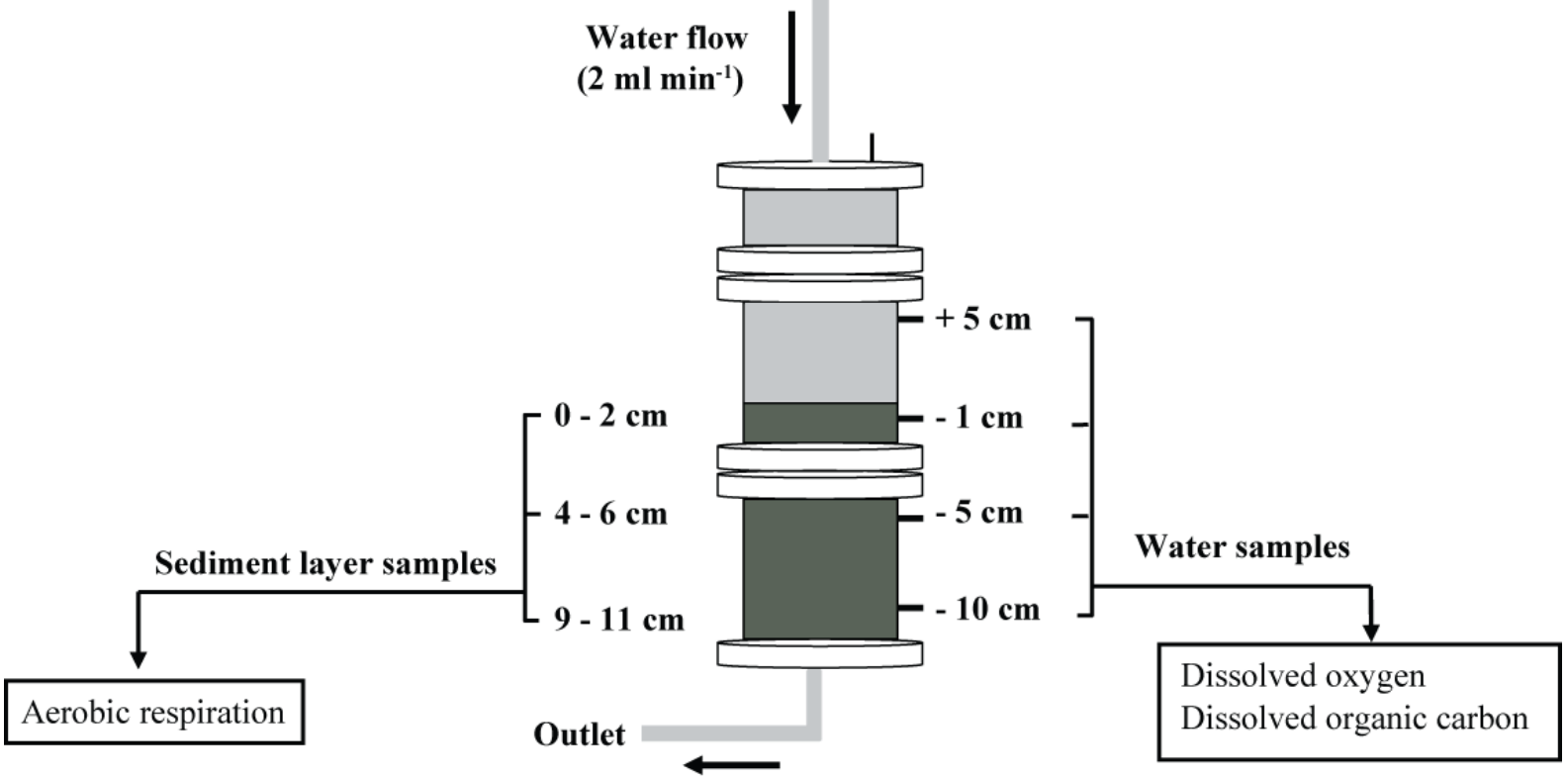

Figure 3: Schematic diagram of a slow filtration column and description of the sampling procedure. 
Figure 4: Foulquier et al.
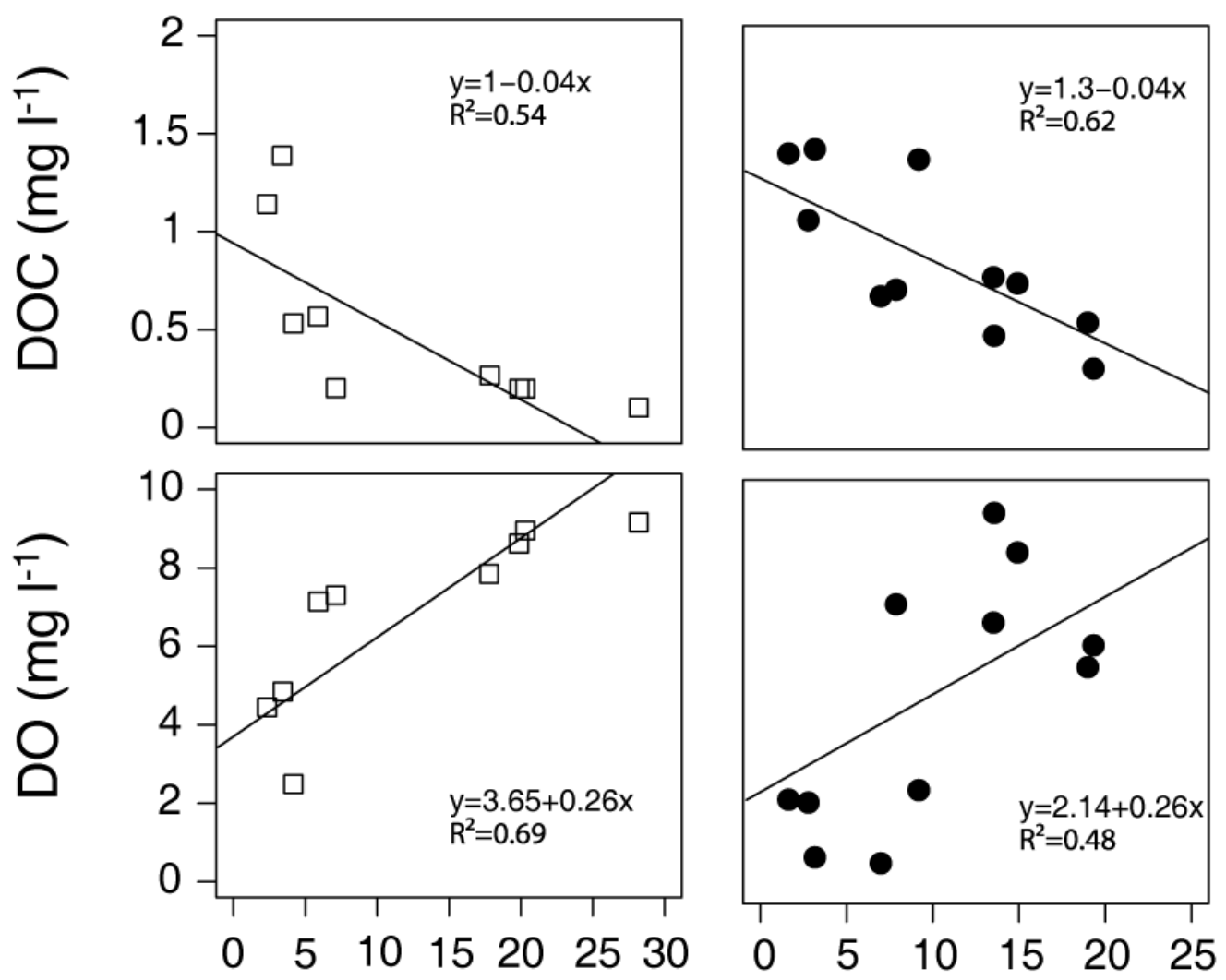

Vadose zone thickness $(\mathrm{m})$ Vadose zone thickness $(\mathrm{m})$

Figure 4: Relationships between the concentrations of dissolved organic carbon (DOC) and dissolved oxygen (DO) in groundwater and vadose zone thickness at reference sites (left panels) and recharge sites (right panels). 
Figure 5: Foulquier et al.
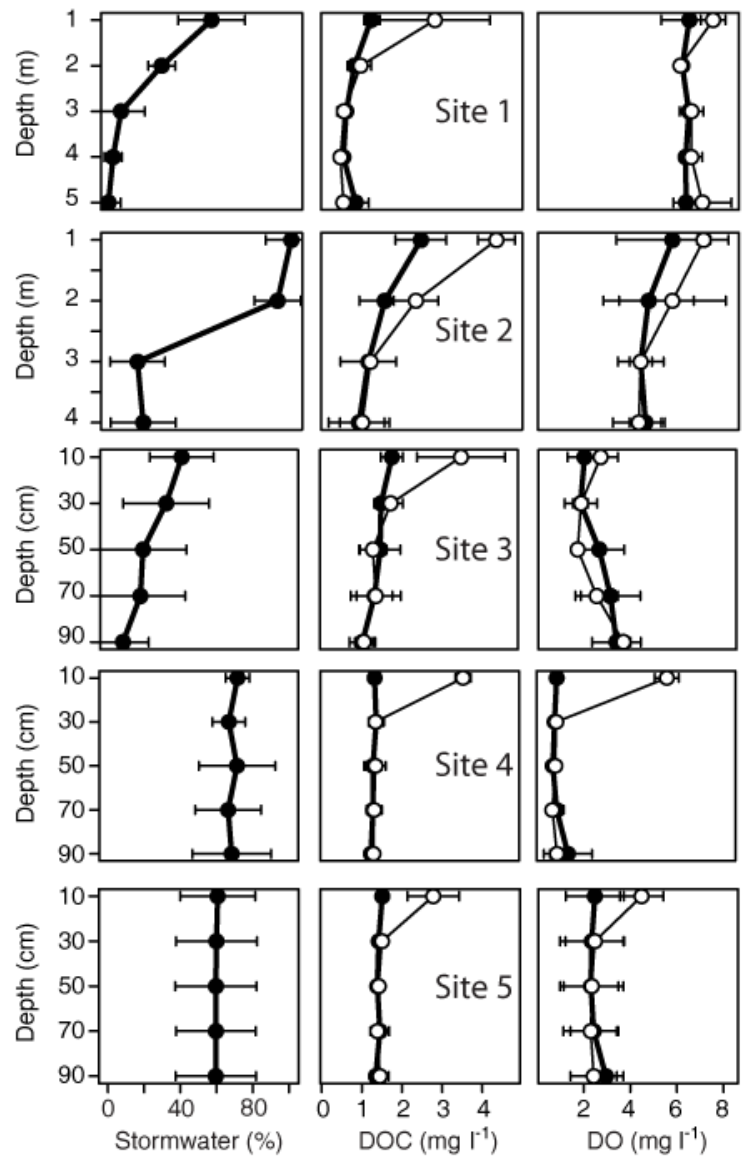

Figure 5: Changes at depth below the groundwater table in: 1) the relative proportion of stormwater into groundwater (left panels); 2) measured (black circles) and calculated (white circles) concentrations of dissolved organic carbon (DOC) (middle panels) and; 3 ) measured (black circles) and calculated (white circles) concentrations of dissolved oxygen (DO) (right panels). Horizontal bars show \pm 1 standard deviation for 3 rainfall events at sites 1 and 2 and 3 replicate wells at sites 3 to 5 . 
Figure 6: Foulquier et al.
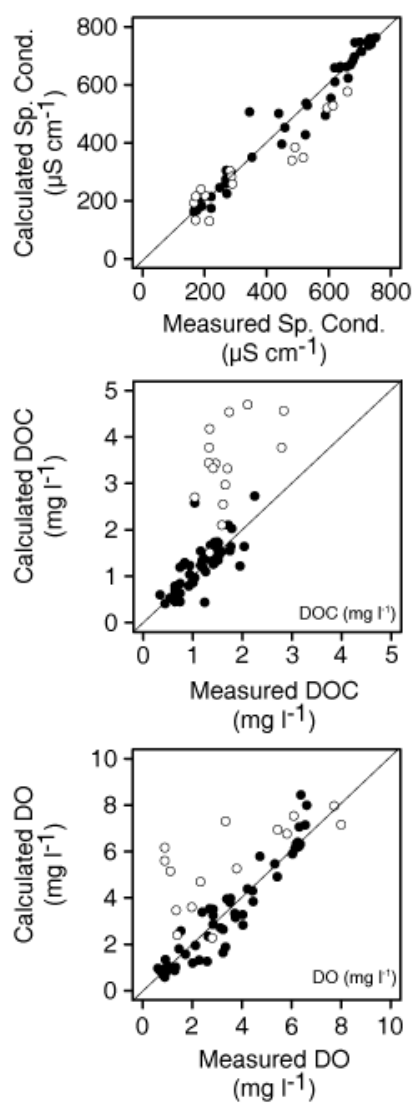

Figure 6: Calculated values from the two-end member mixing model based on chloride concentrations versus measured values for specific conductance (Sp. Cond.), dissolved organic carbon (DOC), and dissolved oxygen (DO). Values $(n=72)$ were from all sites, dates and depths. White symbols correspond to the uppermost depth. The line indicates 1:1 equivalence relationships. 
Figure 7: Foulquier et al.
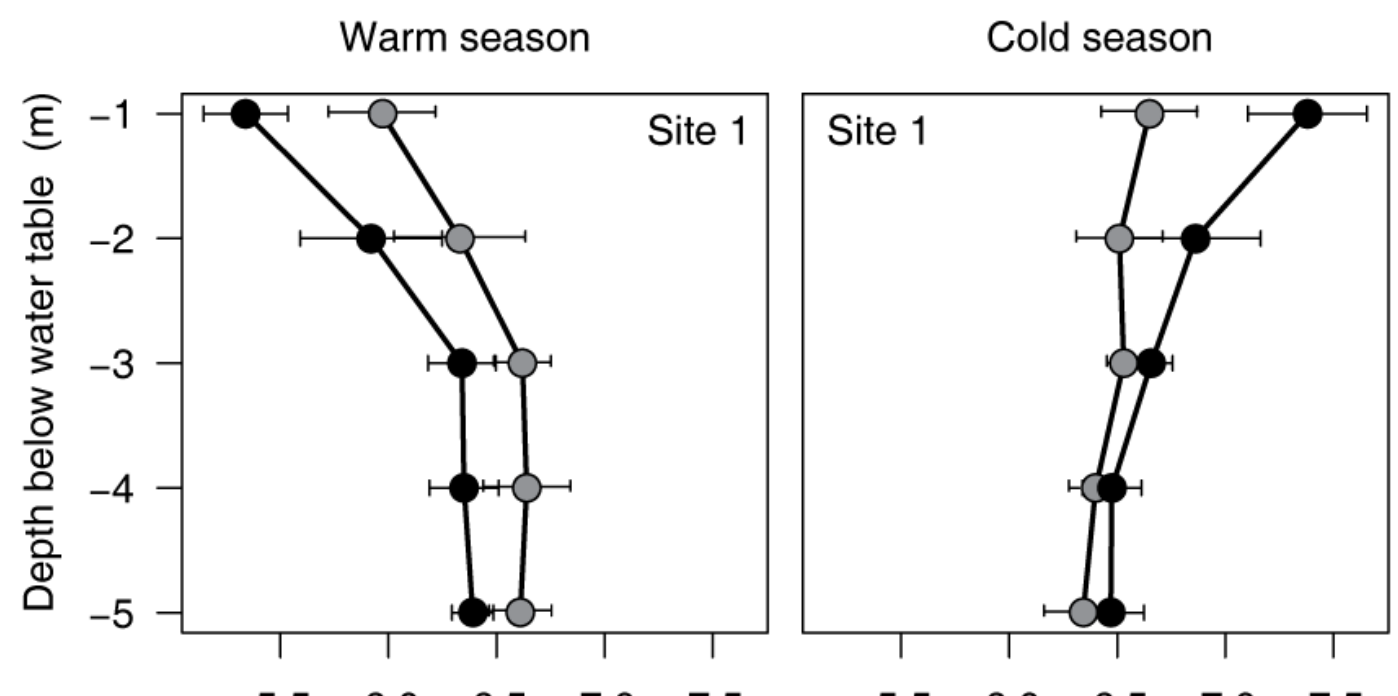

$\begin{array}{lllll}5.5 & 6.0 & 6.5 & 7.0 & 7.5\end{array}$

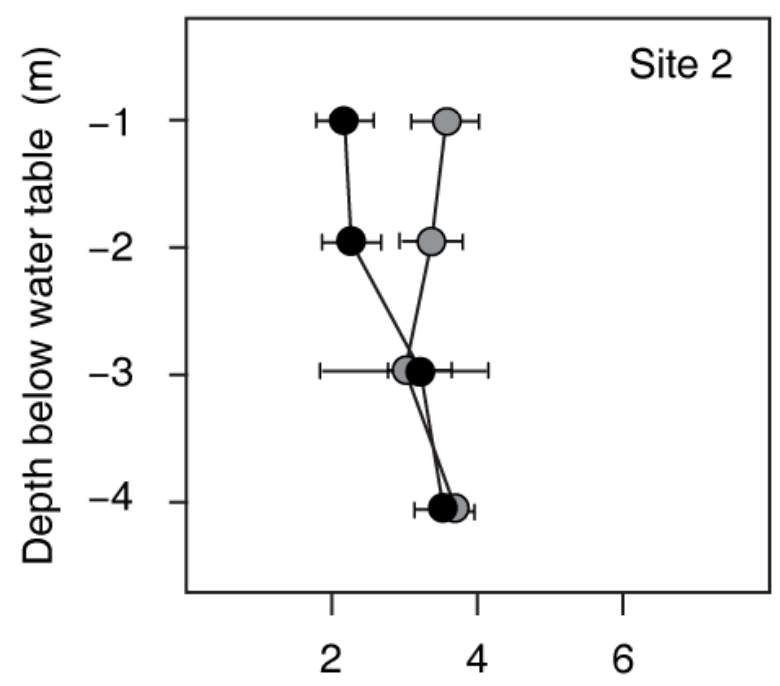

Dissolved oxygen $\left(\mathrm{mg} \mathrm{l}^{-1}\right)$

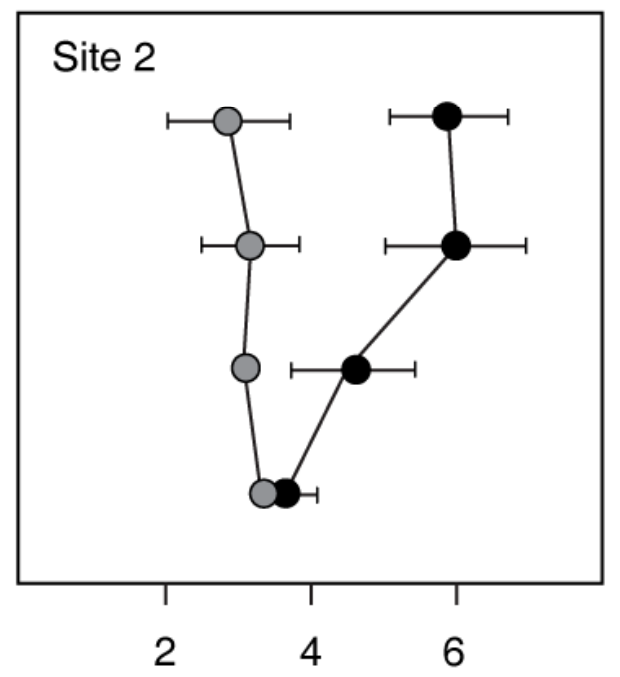

Dissolved oxygen $\left(\mathrm{mg} \mathrm{l}^{-1}\right)$

Figure 7: Vertical gradients of dissolved oxygen below the groundwater table at recharge sites 1 and 2 before (grey circles) and after (black circles) rainfall events during the warm (left panels) and cold (right panels) seasons. Horizontal bars show \pm 1 standard deviation for multiple rainfall events ( $\mathrm{n}=5$ warm events and 5 cold events at site $1 ; \mathrm{n}=6$ warm and cold events at site 2 ). 
Figure 8: Foulquier et al.

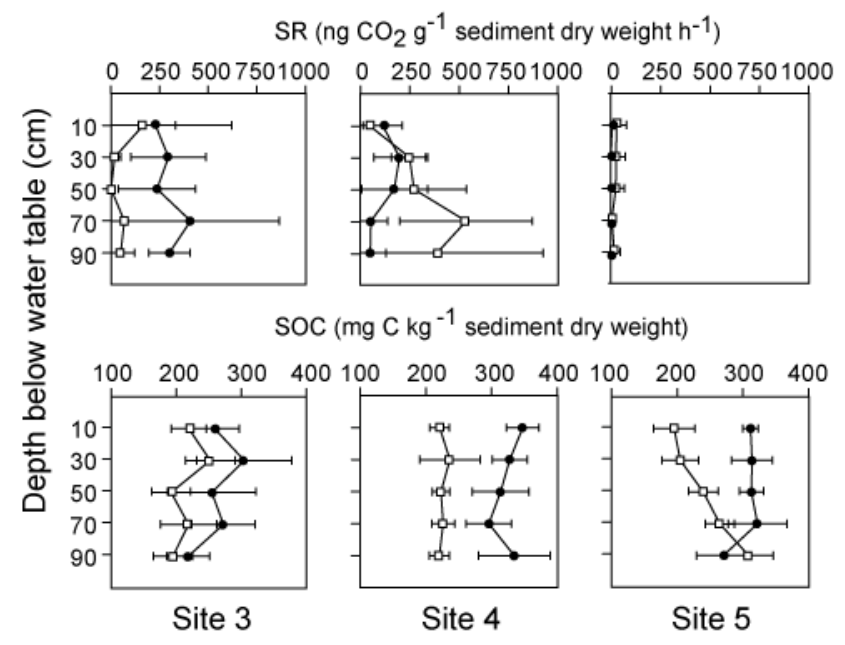

Figure 8: Changes at depth below the groundwater table in sediment respiration (SR) and sedimentary organic carbon (SOC) in upstream (white square) and downstream (black circles) well clusters at sites 3 to 5 . Horizontal bars show \pm 1 standard deviation for 3 replicate wells. 
Figure 9: Foulquier et al.
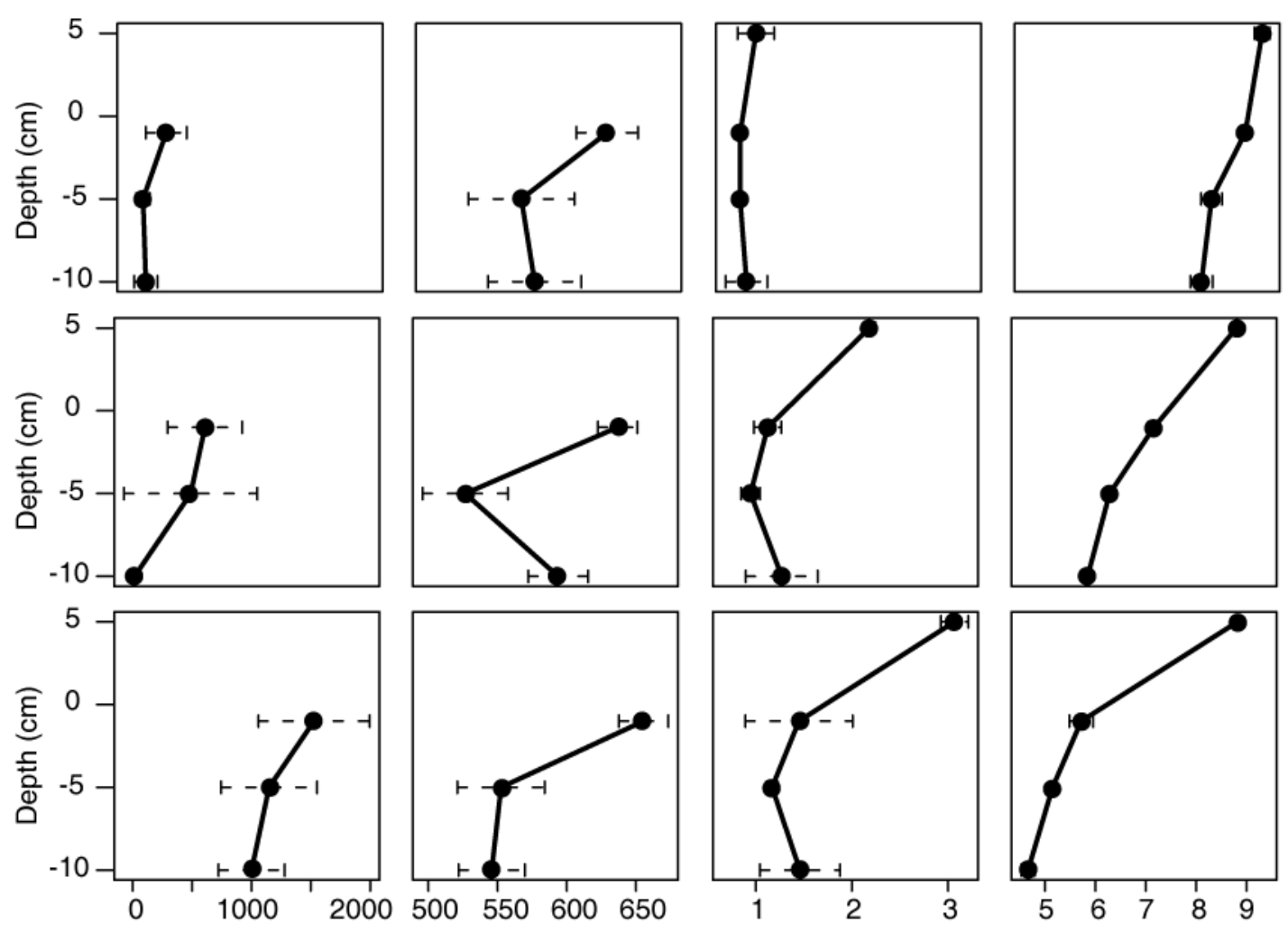

$\mathrm{SR}$ (ng $\mathrm{CO}_{2} \mathrm{~g}^{-1}$ dry

$\mathrm{SOC}$ ( $\mathrm{mg} \mathrm{C} \mathrm{kg-1}^{-1}$ dry sediment)

$\mathrm{DOC}\left(\mathrm{mg} \mathrm{l}^{-1}\right)$

$\mathrm{DO}\left(\mathrm{mg} \mathrm{l}^{-1}\right)$

Figure 9: Vertical gradients of sediment respiration (SR), sedimentary organic carbon (SOC), dissolved organic carbon (DOC) and dissolved oxygen (DO) at day 26 in slow filtration columns supplied with water containing 0.5 (upper panels), 1.5 (middle panels) and 2.5 (lower panels) $\mathrm{mg} \mathrm{C}$ - sodium acetate $\mathrm{l}^{-1}$. 
Table 1: Foulquier et al.

Table 1: Characteristics of recharge (below stormwater infiltration basins) and reference sites. Recharge at reference sites was derived only from the natural infiltration of rainwater $\left(0.24 \mathrm{~m}^{3} \mathrm{~m}^{-2}\right)$

\begin{tabular}{ccrrrr}
\hline Site & Type & $\begin{array}{c}\text { Vadose } \\
\text { zone thick- } \\
\text { ness (m) }\end{array}$ & $\begin{array}{c}\text { Catchment } \\
\text { area (ha) }\end{array}$ & $\begin{array}{c}\text { Basin area } \\
\text { (ha) }\end{array}$ & $\begin{array}{r}\text { Annual } \\
\text { recharge } \\
\left(\mathrm{m}^{3} \mathrm{~m}^{-2}\right)\end{array}$ \\
\hline $1 *$ & Recharge & 19.0 & 180.0 & 1.00 & 52.6 \\
$2 *$ & Recharge & 2.8 & 2.5 & 0.08 & 9.7 \\
$3 \mathrm{D} *+$ & Recharge & 1.7 & 100.0 & 0.40 & 73.1 \\
$4 \mathrm{D} *+$ & Recharge & 3.2 & 270.0 & 0.39 & 202.3 \\
$5 \mathrm{D} *+$ & Recharge & 2.8 & 2.5 & 0.08 & 9.7 \\
6 & Recharge & 13.6 & 45.0 & 0.08 & 160.4 \\
7 & Recharge & 15.0 & 51.0 & 0.12 & 119.7 \\
8 & Recharge & 13.5 & 74.0 & 0.77 & 28.0 \\
9 & Recharge & 9.2 & 33.7 & 0.11 & 89.5 \\
10 & Recharge & 7.9 & 145.0 & 0.77 & 55.0 \\
11 & Recharge & 19.3 & 50.0 & 0.15 & 97.4 \\
12 & Recharge & 7.0 & 285.0 & 0.90 & 92.5 \\
$3 \mathrm{U} * \neq$ & Reference & 2.4 & & & \\
$4 \mathrm{U} * \neq$ & Reference & 3.5 & & & \\
$5 \mathrm{U} * \neq$ & Reference & 4.2 & & & \\
13 & Reference & 28.2 & & & \\
14 & Reference & 17.8 & & & \\
15 & Reference & 20.3 & & & \\
16 & Reference & 5.9 & & & \\
17 & Reference & 7.1 & & & \\
18 & Reference & 19.9 & & & \\
\hline
\end{tabular}

* Well cluster sites

+ Downstream well clusters

₹ Upstream well clusters 


\section{Table 2: Foulquier et al.}

Table 2: Results of analysis of covariance for testing the effect of vadose zone thickness (VZT) and recharge on the concentrations of dissolved organic carbon (DOC) and dissolved oxygen (DO).

\begin{tabular}{lrrrcrc}
\hline & \multicolumn{3}{c}{ DOC } & \multicolumn{2}{c}{ DO } \\
& df & \multicolumn{1}{c}{$F$} & $p$ & \multicolumn{1}{c}{$F$} & $p$ \\
\hline VZT & 1 & 21.72 & 0.0003 & 17.70 & 0.0006 \\
Recharge & 1 & 8.33 & 0.0107 & 4.84 & 0.0429 \\
Recharge $\times$ VZT & 1 & 0.55 & 0.4705 & 1.34 & 0.2631 \\
Error & 16 & & & & \\
\hline
\end{tabular}


Table 3: Foulquier et al.

Table 3: Results of nested analysis of variance for testing the effect of recharge and depth below the groundwater table on sediment respiration (SR), sedimentary organic carbon (SOC) and the concentrations of dissolved organic carbon (DOC) and dissolved oxygen (DO) in groundwater.

\begin{tabular}{lccrrrrrrr}
\hline & \multicolumn{3}{c}{ SR } & \multicolumn{2}{c}{ SOC } & \multicolumn{2}{c}{ DOC } & \multicolumn{2}{c}{ DO } \\
& df & $F$ & $p$ & \multicolumn{1}{c}{$F$} & $p$ & \multicolumn{1}{c}{$F$} & $p$ & $F$ & $p$ \\
\hline Site & 2 & 0.94 & 0.503 & 0.32 & 0.749 & 0.474 & 0.663 & 0.12 & 0.891 \\
Recharge (Site) & 3 & 2.21 & 0.140 & 17.36 & $<0.001$ & 52.40 & $<0.001$ & $109.59<0.001$ \\
Depth & 4 & 0.93 & 0.492 & 0.33 & 0.853 & 3.79 & 0.050 & 12.12 & 0.002 \\
Site $\times$ Depth & 8 & 0.83 & 0.596 & 1.28 & 0.336 & 0.79 & 0.623 & 0.35 & 0.927 \\
Recharge (Site) $\times$ Depth & 12 & 1.10 & 0.378 & 1.69 & 0.091 & 1.04 & 0.429 & 0.90 & 0.551 \\
Error & 60 & & & & & & & & \\
\hline
\end{tabular}




\section{Table 4: Foulquier et al.}

Table 4: Results of analysis of variance for testing the effect of an increasing supply of labile dissolved organic carbon (DOC as sodium acetate) and depth on sediment respiration (SR), sedimentary organic carbon (SOC) and removal rates of dissolved organic carbon (RR-DOC) and dissolved oxygen (RR-DO) in slow filtration columns.

\begin{tabular}{lcrrrrrrrr}
\hline & \multicolumn{1}{c}{ SR } & \multicolumn{2}{c}{ SOC } & \multicolumn{2}{c}{ RR-DOC } & \multicolumn{2}{c}{ RR-DO } \\
& df & \multicolumn{1}{c}{$F$} & \multicolumn{1}{c}{$p$} & \multicolumn{1}{c}{$F$} & \multicolumn{1}{c}{$p$} & \multicolumn{1}{c}{$F$} & \multicolumn{1}{c}{$p$} & \multicolumn{1}{c}{$F$} & \multicolumn{1}{c}{$p$} \\
\hline DOC supply & 2 & 45.11 & $<0.001$ & 0.06 & 0.944 & 4.43 & 0.027 & $101.78<0.001$ \\
Depth & 2 & 6.43 & 0.014 & 27.84 & $<0.001$ & 41.07 & $<0.001$ & $674.36<0.001$ \\
DOC supply $\times$ depth & 4 & 1.76 & 0.212 & 2.37 & 0.091 & 5.80 & 0.003 & $78.18<0.001$ \\
Error & 18 & & & & & & & & \\
\hline
\end{tabular}

